\title{
STUDY OF INCIDENCE OF GONORRHOEA IN REPRODUCTIVE AGE GROUP WOMEN WITH LEUCORRHOEA ATTENDING STI CLINIC
}

\author{
M. Parvathi ${ }^{1}$, P. Guru Prasad ${ }^{2}$, G. Lavanya ${ }^{3}$, Y. Swapna Priya ${ }^{4}$, Rashmi Naldeega $^{5}$ \\ ${ }^{1}$ Assistant Professor, Department of Dermatology, Venereology \& Leprosy, Andhra Medical College. \\ ${ }^{2}$ Associate Professor, Department of Dermatology, Venereology \& Leprosy, Andhra Medical College. \\ ${ }^{3}$ Post Graduate, Department of Dermatology, Venereology \& Leprosy, Andhra Medical College. \\ ${ }^{4}$ Senior Resident, Department of Dermatology, Venereology \& Leprosy, Andhra Medical College. \\ 5 Post Graduate, Department of Dermatology, Venereology \& Leprosy, Andhra Medical College.
}

\section{ABSTRACT}

The object of our study is to know the incidence of gonorrhea in reproductive age group women suffering with leucorrhoea attending STI Clinic in King George Hospital in Visakhapatnam.

\section{MATERIAL AND METHODS}

In our present study, we included 120 female patients of reproductive age group women (20-45 years) with leucorrhoea attending STI Clinic; we also examined the male partners. The diagnosis of Gonorrhoea is confirmed by smear and culture examination. The vaginal discharge was collected with sterile swabs and inoculated in modified Thayer-Martin media for $48-72$ hours. Gram staining was done to examine the smear under microscope to examine the diplococci. Urethral and rectal swabs collected from their male sexual partners and sent for smear and culture.

\section{RESULTS}

In our study, results shows women suffering with Gonococcal infection and some percent of male partners suffering with Gonococcal infection and it shows the transmission occurs predominantly through sexual contact are asymptomatic carriers and source of infection to their male partners. We found Gonorrhoea is the common cause of Leucorrhoea next to Candidiasis and Trichomoniasis.

\section{CONCLUSION}

Treatment of both male and female sexual partners is essential to control and prevent the recurrence of Gonorrhoea. Early diagnosis and treatment of Gonorrhoea in female patients will prevent late complications like PID, tubal block, ectopic pregnancy and sterility in reproductive age group women.

\section{KEYWORDS}

Leucorrhoea, Gonorrhoea.

HOW TO CITE THIS ARTICLE: M. Parvathi, P. Guru Prasad, G. Lavanya, Y. Swapna Priya, Rashmi Naldeega. "Study of Incidence of Gonorrhoea in Reproductive Age Group Women with Leucorrhoea Attending STI Clinic." Journal of Evolution of Medical and Dental Sciences 2015; Vol. 4, Issue 99, December 10; Page: 16470-16472, DOI: 10.14260/jemds/2015/2444

\section{INTRODUCTION}

Gonorrhoea is one of the most common sexually transmitted disease caused by Neisseria gonococci. It is a gram negative, non-motile, non-sporing diplococcic. In female genital tract, the endo-cervix, fallopian tube and endometrium of uterine cavity are lined by columnar epithelium and more susceptible to gonococcal infection. In male patients, penile urethra is lined by columnar epithelium and gonococcal urethritis is more common. ${ }^{1}$

Excessive abnormal vaginal discharge is called as Leucorrhoea and it is one of the most common complaint in female patients attending STI Clinics.

Financial or Other, Competing Interest: None.

Submission 12-11-2015, Peer Review 13-11-2015,

Acceptance 23-11-2015, Published 10-12-2015.

Corresponding Author:

M. Parvathi,

C/o. G. Santha Rao,

Do. No. 7-5-92,

Pandurangapuram,

Visakhapatnam-530003.

E-mail: parvathi2448@gmail.com

DOI: $10.14260 /$ jemds/2015/2444
The common organisms causing Leucorrhoea are Candida albicans, Trichomonas vaginalis and Gardnerella vaginalis. $^{2}$

The consistency and nature of discharge varies with organism. In Candidiasis the discharge is white, curdy in nature, associates with vaginal soreness, burning and itching. In Trichomoniasis the vaginal discharge is yellowish and frothy in nature with intensive vulval itching. In bacterial vaginosis the discharge is homogenous, sticky, offensive, fishy mal-odour. In gonorrhoea the discharge is greenish yellow, profuse and purulent in nature.

\section{MATERIALS AND METHODS}

In our present study, we included 120 female patients attending STI Clinic of reproductive age group (20-45), who lead active sexual life. We excluded women below 20 years and above 45 years. We also included male sex partners of female patients to know the source of infection and route of transmission. We screened all the patients by doing HIV and VDRL tests. Discharge samples were taken with sterile swabs from endo-cervix, rectum, urethra and oropharynx Lab. 


\section{DIAGNOSIS}

The collected swabs transported to the micro labs in Stuart's medium and inoculated In Modified Thayer-Martin medium for 48-72 hours. Modified Thayer Martin medium contains Vancomycin, Trimethoprim and Nystatin to inhibit the growth of other contaminated bacteria and fungus. ${ }^{3}$ After 48 hours of inoculation pink color colonies appear in culture media identified by doing oxidase test, which turn pink color to dark blue color. The smear was taken on glass slide, fixed and dried and stained with gram staining. Examination of smear under oil immersion bean shaped intracellular diplococci observed. ${ }^{3,4}$ Other tests like gonococcal compliment fixation and ELISA tests were not done due to unavailability in our lab. We have done $\mathrm{KOH}$ and saline wet mount to exclude candida and trichomonal infections.

\section{OBSERVATION AND RESULTS}

In our present study, 120 female patients with leucorrhoea attending STI Clinic were taken. According to their marital status $108(90 \%)$ patients were married, $8(6.66 \%)$ patients unmarried and $4(3.33 \%)$ patients were commercial sex workers. \{Table-1\}. In our study, we have taken 120 female patients of reproductive age group. We excluded patients below 20 years and above 45 years. \{Table-2\} shows majority of patients $32 \%$ belonged to $25-30$ years age group. Only $8 \%$ of patients come under 40-45 years age group. Culture and smear examination were done for all 120 female patients and their male sexual partners. Out of 120 female patients, $22.5 \%$ were gonococcal smear positive and $17.5 \%$ were positive for gonococcal culture. Out of 120 male partners, 32\% were gonococcal smear positive and $22.5 \%$ gonococcal culture positive \{Table-3\}. \{Table 4 \} shows $32.5 \%$ of female patients were smear positive for $\mathrm{KOH}$ mount (Candidiasis), $26.5 \%$ of female patients showed positive for wet mount (Trichomoniasis), $22.5 \%$ of patients were positive for Gonococcal infection, others were non-specific (18.3\%). Out of 120 female patients, we found $8(6.6 \%)$ were VDRL reactive and $3(2.5 \%)$ were HIV seropositive. Out of 120 male partners, we found $14(11.6 \%)$ were VDRL reactive and $5(4.1 \%)$ were HIV seropositive.

\begin{tabular}{|c|c|c|}
\hline Marital Status & No. of Patients & Percentage \\
\hline Married & 108 & $90 \%$ \\
\hline Unmarried & 8 & $6.66 \%$ \\
\hline Commercial Sex Workers & 4 & $3.33 \%$ \\
\hline Total & $\mathbf{1 2 0}$ & $\mathbf{1 0 0} \%$ \\
\hline Table 1: Distribution of patients according to \\
marital status of patients \\
\hline
\end{tabular}

\begin{tabular}{|c|c|c|}
\hline Age Group & No. of Patients & Percentage \\
\hline $20-25$ yrs. & 33 & $27.5 \%$ \\
\hline $25-30$ yrs. & 38 & $32 \%$ \\
\hline $30-35$ yrs. & 24 & $20 \%$ \\
\hline $35-40$ yrs. & 15 & $12.5 \%$ \\
\hline $40-45$ yrs. & 10 & $8 \%$ \\
\hline Table 2: Distribution of patients according to Age \\
\hline
\end{tabular}

\begin{tabular}{|c|c|c|c|c|c|}
\hline $\begin{array}{c}\text { Sex of } \\
\text { Patients }\end{array}$ & $\begin{array}{c}\text { Total } \\
\text { Number }\end{array}$ & $\begin{array}{c}\text { Gonococcal } \\
\text { Smear } \\
\text { Positive }\end{array}$ & $\begin{array}{c}\text { Percentage } \\
\text { \% }\end{array}$ & $\begin{array}{c}\text { Gonococcal } \\
\text { Culture Positive }\end{array}$ & $\begin{array}{c}\text { Percentage } \\
\%\end{array}$ \\
\hline $\begin{array}{c}\text { Female } \\
\text { Patients }\end{array}$ & 120 & 27 & $22.5 \%$ & 21 & $17.5 \%$ \\
\hline Male Partners & 120 & 38 & $32 \%$ & 27 & $22.5 \%$ \\
\hline \multicolumn{7}{|c|}{ Table 3: Lab diagnosis of Gonococcal infection } \\
in women and their male sexual partners
\end{tabular}

\begin{tabular}{|c|c|c|}
\hline Infection & $\begin{array}{c}\text { No. of } \\
\text { Patients }\end{array}$ & Percentage \\
\hline Candidiasis (KOH Mount) & 39 & $32.5 \%$ \\
\hline Gonoccocal infection & 27 & $22.5 \%$ \\
\hline $\begin{array}{c}\text { Trichomonas (Wet } \\
\text { Mount) }\end{array}$ & 31 & $26.7 \%$ \\
\hline Non-specific & 23 & $18.3 \%$ \\
\hline Total & 120 & $100 \%$ \\
\hline \multicolumn{3}{|c|}{ Table 4: Etiopathogenesis of Leucorrhoea } \\
\hline
\end{tabular}

\begin{tabular}{|c|c|c|c|c|c|}
\hline $\begin{array}{c}\text { Sex of } \\
\text { Patients }\end{array}$ & $\begin{array}{c}\text { Total } \\
\text { Patients }\end{array}$ & \multicolumn{2}{c|}{$\begin{array}{c}\text { Sero } \\
\text { Positive } \\
\text { for VDRL\% }\end{array}$} & \multicolumn{2}{c|}{$\begin{array}{c}\text { Sero } \\
\text { Positive } \\
\text { for HIV\% }\end{array}$} \\
\hline $\begin{array}{c}\text { Female } \\
\text { patients }\end{array}$ & 120 & 8 & $6.6 \%$ & 3 & $2.5 \%$ \\
\hline Male partners & 120 & 14 & $11.6 \%$ & 5 & $4.1 \%$ \\
\hline \multicolumn{3}{|c|}{$\begin{array}{c}\text { Table 5: Screening for associated } \\
\text { infections syphilis and HIV }\end{array}$} \\
\hline
\end{tabular}

\section{DISCUSSION}

Gonorrhoea is one of the most common STI infection that can cause leucorrhoea in female patients. In our study, we found incidence of Gonorrhoea in $22.5 \%$ of the female patients with reference to other studies at the rate of $28 \%$ and $32 \%$ incidence.5,6 In screening of male sexual partners, we found $32 \%$ were gonococcal smear positive indicates female patients acquire infection from their male sexual partners. In our study according to etiopathogenesis, we found $32.5 \%$ of female patients with leucorrhoea was due to Candidiasis and $26.7 \%$ patients with Trichomoniasis and $22.5 \%$ due to Gonorrhoea.

It indicates next to Candidiasis and Trichomoniasis, Gonococcal infection found to be the third common cause of leucorrhoea in reproductive age group of women.5,7 According to age-wise distribution, higher incidence of gonorrhea found in 20-30 years of age group which is sexually active age group. In our study, we found lower incidence found after 45 years. We screened male and female sexual partners for association infections like syphilis and HIV and $2.5 \%$ female patients and $4.1 \%$ of their male sexual partners are HIV reactive shows that leucorrhoea may enhance the risk of HIV transmission. 


\section{Treatment and Follow-Up}

The confirmed cases of Gonorrhoea were treated with single dose of tab. Cefixime $400 \mathrm{mg}$ orally or tab. Ofloxacin $400 \mathrm{mg}$ single dose orally. Simultaneously, the male sexual partners of female patients were also given the same treatment. We follow up the patients for a period of 3 to 6 months. Those patients with persistent symptoms, we treat them for mixed infections with tab. Azithromycin 1gm orally and tab. Metronidazole 2gm single dose.

\section{CONCLUSION}

Gonococcal infection is one of the most common cause of leucorrhoea in reproductive age group.

Male sexual partners are found to be common source of infection in female patients, so simultaneous treatment of both female and male sexual partners is essential to prevent recurrence and recycling of infection. Early diagnosis and treatment of Gonorrhoea in female patients of reproductive age group women may prevent late complications like tubal block, sterility and ectopic pregnancy.

\section{REFERENCES}

1. Gonorrhoea in males. In: King A, Nicol C, Rodin Peds. Venereal diseases. $4^{\text {th }}$ edn. London: ELBS; 1980.p.200213.

2. Thin RN, Shav EJ. Diagnosis of gonorhhoea in women. $\mathrm{Br}$ J Vener Dis 1979;55:10-13.

3. Gonorrhoea. In: Dyck EV, Meheus AZ, Piot P, eds. Laboratory diagnosis of sexually transmitted diseases. Geneva: WHO; 1999. p.1-21.

4. Hook EW, Homes KK. Gonococcal infection. Ann Intern Med 1985;102:229-243.

5. Adler MW, Belsey EM, Rogers JS. Sexually transmitted diseases in a defined population. Br Med J 1981;283:2932. 6.

6. Bhattacharyya MN, Jephcott AE, Morton RS. Diagnosis of gonorrhoea in women: comparison of sampling sites. $\mathrm{Br}$ Med J 1973;2:748-50. 5.

7. Turner CF, Rogers SM, Miller HG, Gribble JN, et al. Untreated gonoccocal and chlamydial infections in a probability sample of adults. JAMA 2002;287:726-733. 